\title{
Morphogenetic identification, description and pathogenicity of novel pathogens on Iraqi wheat plant (Triticum aestivum) causing head blight and crown rot diseases
}

\author{
MOHANAD KHALAF MOHAMMED-AMEEN ${ }^{1, \diamond »}$, MOHAMMED HUSSEIN MINATI ${ }^{2, \bullet}$, \\ MOHAMMED HAMZA ABASS ${ }^{3, \text { r४ }}$

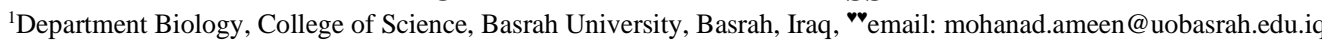 \\ ${ }_{2}^{2}$ Department Biology, College of Education-Al-Qurna, Basrah University, Basrah, Tel/fax. +96-47710803047, ”email: abo_azher70@yahoo.com

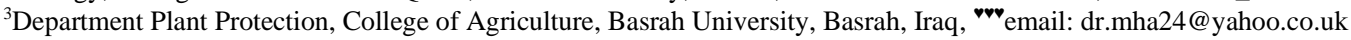

Manuscript received: 21 March 2021. Revision accepted: 30 April 2021.

\begin{abstract}
Mohammed-Ameen MK, Minati MH, Abass MH. 2021. Morphogenetic identification, description and pathogenicity of novel pathogens on Iraqi Wheat Plant (Triticum aestivum) causing head blight and crown rot diseases. Biodiversitas 22: 2999-3005. Wheat (Triticum aestivum L.) plant suffers from several fungal diseases, such as Fusarium head blight, root rot, and crown rot diseases that reduce the quality and quantity of grains. Two Fusarium species (Fusarium brachygibbosum and F. falciforme) have been isolated from wheat roots and rhizosphere regions showing disease symptoms in wheat fields in Al-Hwuir and Al-Qurna districts at Basra province. Each fungal species had been characterized morphologically and molecularly based on DNA sequence data for the translation elongation factor 1- $\alpha$ $(T E F-1 \alpha)$. Results of pathogenicity test showed that $F$. falciforme and $F$. brachygibbosum at the third week of inoculation induced head bleached symptoms with the severity of $12.46 \%$ (with significant differences P > 0.05) and 7.14\%, respectively on Abu Ghraib 3 cultivar. Yellowing and necrosis symptoms were recorded in stem and crown region. The mean of disease severity (as necrosis on basal stem and crown) was 5\% and 3.34\% for F. falciforme and F. brachygibbosum, respectively. The two Fusarium species were identified as new pathogens on wheat plants in Iraq, causing head bleaching, stem and crown necrosis.
\end{abstract}

Keywords: Fusarium crown rot, head blight, morphological, phylogenetic, TEF-1 $\alpha$, wheat

\section{INTRODUCTION}

Wheat (Triticum aestivum L.) is one of the most important cereal crops in the world, providing $55 \%$ of carbohydrates and $20 \%$ of the total consumed food calories (Shewry and Hey 2015). It is an important nutritious crop that consists mainly of starch $(59 \%)$; protein $(12.6 \%)$; fat $(1.6 \%)$ and other components (Kreft 2016). In Iraq, wheat is a staple food for the most population; According to (FAO 2020), the total production of wheat in 2020 was 734 million tonnes, that 3.2 million tonnes from Iraq. Fusarium is well known important fungal genus that causes different diseases in humans; animals and plants. The genus of Fusarium consists of many important species, which are identified as plant pathogens causing important diseases such as Fusarium wilt (FW); Fusarium head blight (FHB); Fusarium root rot (FRR); Fusarium crown rot (FCR), and many other diseases (Nelson et al. 1994). On cereals, Fusarium species infect different plant parts such as grains, seedlings, heads, roots, and shoot systems that cause significant reduction in yield and their quality (Polišenská et al. 2019).

The major cereal pathogen is $F$. graminearum, which caused head blight disease on wheat. In addition, several Fusarium species have been identified as an FHB pathogen including $F$. culmorum and $F$. avenaceum (Basler 2016). Thokala et al. (2015) showed that a group of Fusarium species $(F$. semitectum; $F$. equiseti; $F$. poae; $F$. sporotrichioides; $F$. tricinctum; $F$. acuminatum; $F$. subglutinans; $F$. solani and $F$. oxysporum) has been associated with cereal diseases. The earliest reports on FHB and FCR caused by F. roseum were published in 1917 (Tryon 1917).

Recently, several studies have been reported many Fusarium species, such as $F$. pseudograminearum, $F$. graminearum, $F$. culmorum, $F$. nygamai, $F$. solani, $F$. avenaceum, $F$. chlamydosporum, $F$. cerealis, and $F$. equiseti) causing FHB, FCR, and Fusarium root rot (FRR) on Iraqi wheat crop, the last six species were identified for the first time on wheat by the same authors of this study (Minati and Mohammed-Ameen 2019a, b, c, d, 2020).

In Oman, $F$. brachygibbosum was found to be the causal agent of dieback disease of Euphorbia larica (AlMahmooli et al. 2013), another report showed that $F$. brachygibbosum has been associated with wild grass inflorescence by Davari et al. (2014). Additionally, this Fusarium sp. was first reported in Iran as a true pathogen of Oleander (Nerium oleander) causing leaf spot disease (Mirhosseini et al. 2014). In 2015, Rentería-Martínez et al. (2015) reported $F$. brachygibbosum as a true pathogen on watermelon with wilting symptoms, while Saleh et al. (2017) isolated the same species from diseased samples of date palm (Phoenix dactylifera).

In $2017, F$. brachygibbosum was reported on the olive tree as a causal agent of dieback disease (Trabelsi et al. 2017). It has also been isolated from cereal grains (wheat; 
rice; barley and corn) and their products (starch and flour) (El-Rabbat et al. 2018). Recently, Punja et al. (2018) identified this species as a true pathogen on Marijuana (Cannabis sativa L.) plants.

$F$. falciforme has been isolated from many plants and soil such as bark and soil of peat and pine (Chehri et al. 2015); root of Lima Bean (Phaseolus lunatus L.) (Sousa et al. 2017). Recently, this species has been identified as a new species in Western Iran (Siahpoush and Darvishnia 2018) in Poaceae plants.

There is no previous report available in the Iraqi literature on $F$. brachygibbosum and $F$. falciforme on wheat plants. Therefore, the present study provides complete morphological and molecular description, and also confirms the pathogenicity of both Fusarium species on wheat plants in Basra Province, Iraq.

\section{MATERIALS AND METHODS}

\section{Sample collection}

Plant part samples

Two wheat fields (Mazeara'a and Al-Hwuir) were selected in Basra province and infected plants were collected at the flowering stage (two three weeks before harvest). Stem and rhizosphere samples were collected on April 15 ${ }^{\text {th }}, 2018$.

Plant samples were cut into small pieces and cleaned in running water for 20 mins, sterilized with $6 \%$ sodium hypochlorite for 120- 150 seconds, rinsed in sterile distilled water (SDW) thrice, and then placed on filter papers. After that, 6 pieces were placed on each petri dish containing potato dextrose agar media (PDA), and three replicates were maintained for each. All the plates were incubated at $25^{\circ} \mathrm{C}$ for 5-10 days. The fungi seen in Petri plates were sub-cultured onto water agar (WA), PDA and Spezieller Nahrstoffarmer agar media (SNA) with 3 replicates for identification purpose.

\section{Soil (rhizosphere) samples}

Serial dilution $\left(10^{-6}\right)$ was made for the collected soil samples using SDW. Then, $1 \mathrm{ml}$ from each dilution was transferred onto PDA medium. The Petri dishes were incubated at $25^{\circ} \mathrm{C}$ for 5 days.

\section{Classification by morphotype}

Identification was based on the growth, mycelium color, and culture medium pigmentation. One representative isolate of each morphotype was used for assessment.

\section{Colonies morphology and growth rate}

Detailed morphology of colonies and aerial mycelium pigmentation were carried out (Nelson et al. 1983).

\section{Morphological characterization of Fusarium isolates}

The pure culture of Fusarium isolates were maintained on SNA and PDA plates (Leslie and Summerell 2008). Seven days after incubation at $25^{\circ} \mathrm{C}$, the Fusarium isolates were identified on the basis of size, shape, and color of colony and microscopic features such as chlamydospores, microconidia, and macroconidia.

\section{Molecular identification \\ DNA extraction}

Following the manufacturer's instructions, a fresh colony of Fusarium isolates was extracted to obtain the genomic DNA using the Plant Genomic DNA Mini Kit (GP100) Geneaid protocol.

\section{Polymerase Chain Reaction (PCR) amplification}

The obtained genomic DNA was amplified using forward and reverse primers, EF-1 (5'ATG GGT AAG GAG GAC AAG AC3') and EF-2 (5'GGA AGT ACC AGT GAT CAT GTT3'), for the sequence of $T E F-1 \alpha$ gene as follows: (i) The genomic DNA was amplified with a total volume of $25 \mu \mathrm{L}$, comprise $5 \mu \mathrm{L}$ Master Mix (Bioneer, Korea), $1.5 \mu \mathrm{L}$ of each primer, $5 \mu \mathrm{L}$ of a template genomic DNA, and $12 \mu \mathrm{L}$ of SDW. (ii) The reactions of PCR were performed in DNA Engine Tetrad 2 Peltier Thermal Cycler (BIO-RAD), and the amplification program initiated with denaturation at $95^{\circ} \mathrm{C}$ for 5 minutes, subsequently 35 cycles of half-minute denaturation at $95^{\circ} \mathrm{C}$, half-minute of annealing at $45.5^{\circ} \mathrm{C}$ and minute and half of the extension at $72^{\circ} \mathrm{C}$ followed by a final extension at $72^{\circ} \mathrm{C}$ for 7 minutes. Finally, $1.5 \%$ agarose gel electrophoresis was liquefied in $1 \mathrm{x}$ Tris Borate EDTA (TBE) buffer, blemished with ethidium bromide, imagined under UV transilluminator by GeneSnap photo imaging system (SynGene). (iii) The PCR sequencing products of the tested isolates were aligned with Clustal (ver. 2). The MEGA.X (Kumar et al. 2018) program was used for phylogenetic analysis. Aligned sequences were checked for quality and compared with deposited sequences in Gene-Bank, NCBI, using BLAST.

\section{Pathogenicity test}

This experiment was performed to test the pathogenicity of $F$. brachygibbosum and $F$. falciforme on different parts of the wheat plant (spikes, stems, and grains) of susceptible variety of winter wheat (Abu Ghraib 3). The isolate of $F$. brachygibbosum was obtained from wheat roots in the Al-Hwuir district. While, F. falciforme was obtained from the rhizosphere region of the wheat field located in Al-Qurna district, Basra province. Seeds were sown in pots with a $15-\mathrm{cm}$ diameter. Soil mixture was prepared from silt loam soil, peat moss, and sand with a volume ratio of $(1: 1: 1)$ after autoclaving it at $121^{\circ} \mathrm{C}$ and pressure 1 bar, one hour, twice for two days).

To determine the pathogenicity, a mycelium plug $(0.5$ $\mathrm{cm}$ ) of PDA medium was taken from the developing edges of each isolate and inoculated in $7 \mathrm{~cm}$ depth of the soil mixture. Seeds were disinfected with $70 \%$ ethanol for one min, $10 \%$ sodium hypochlorite for $2 \mathrm{~min}$, then rinsed in SDW thrice and dried up on filter paper. Prepared seeds were sown on the $1^{\text {st }}$ Dec. 2018 with a rate of 7 seeds per pot. Three replicates for each isolate were maintained. Pots were kept in a greenhouse bench and reserved in $22^{\circ} \mathrm{C}$ day $/ 17^{\circ} \mathrm{C}$ night \pm 3 . After seedling emergence, plants (five per pot) were thinned and fertilized weekly with 20-20-20 (N-P-K) solution at $1 \%$ concentration, 5 weeks after 
planting. Each plant was rated for brown spots that occurred on the stem and crown depending on the percentage of part area stained. A 0 to 4 scale Ledingham et al. (1973) was followed for stem and crown symptoms: 0 $=$ no symptom, $1=$ whit $-25 \%$ of surface area browned, 2 $=25-50 \%, 3=50-75 \%$ and $4=75-100 \%$ (damping off).

For evaluating pathogenicity on wheat heads, seeds were sown in the same soil mixture in different pots but with no mycelial plugs. Each isolate was grown on PDA for 7 days at $25^{\circ} \mathrm{C}$. After 20-25 days before maturity, three spikes in each pot were inoculated with a spore suspension. Fusarium cultures were identified and transferred on a new media to obtain a single-spore culture.

At mid-anthesis, spikes were sprayed by a spore suspension of $F$. brachygibbosum and $F$. falciforme $(1 \times$ $10^{6}$ conidia per $\left.\mathrm{ml}\right)$. One droplet of Tween 20 (polyoxyethylene sorbitan monolaurate) was mixed in every $200 \mathrm{ml}$ of spore suspension. Spikes sprayed with sterile distilled water served as control. For incubation, plants were covered with wet black plastic bags for $48 \mathrm{~h}$. After incubation, wheat plants were set aside until maturity under similar conditions (mentioned above). Visually, each spike was rated for infected surface part in symptom percentage of Fusarium head blight at 7, 14, and 21 days after inoculation. Each experiment was performed with triplicates according to randomized complete block design (RCBD).

\section{RESULTS AND DISCUSSION}

\section{Morphological and microscopic description of fungi Fusarium brachygibbosum Padwick}

On PDA media it produces aerial white hyphae, pinkish, and blood-red color colonies (Figure 1.A and 1.B). Conidiophores were colorless, thin-walled, polyphialides, and monophialides. Conidiogenous cells were terminal, producing conidia from the apex in succession. Conidia were also colorless, ellipsoidal, and aseptate. Chlamydospores were produced abundantly, either singly or in chains. The macroconidia were elongated (swollen), terminal, and sometimes intercalary. Macroconidia were 35 septate; the middle cells were slightly wider than other cells and curved into the basal part for the intermediate cells. A hook-shaped apical cell was common in footshaped basal cells. The microconidia were oval and usually one to two septa or none (Figure 1.C and 1.D).

\section{Fusarium falciforme (Carrion) Summerb. \& Schroers}

The morphology of fungal colonies on PDA was offwhite to pinkish and sometimes fluffy (Figure 2.A-B). Conidiophores were sparse with inconstant length, pale color, thin-walled, septate, pointed toward the apex, and not divided into branches. Terminal conidiogenous cells produced conidia from the apex in acropetal succession. Conidia were pale, ellipsoidal to reniform, aseptate or septate, occasionally having a truncated base, or gathered in a group. Chlamydospores were produced abundantly, individually or in chains, terminal or intercalary, stretched out or inflated, with thin or distended walls. Macroconidia were wide, straight to slightly curved, with parallel ventral and dorsal planes. The apical cells were rounded, basal cells were straight and cylindrical with a barely truncated or rounded end. Each microconidium was pyriform to fusiform shaped, having a truncated basal part, and usually one or two septa or none (Figure 2.C, 2.D, and 2.E).
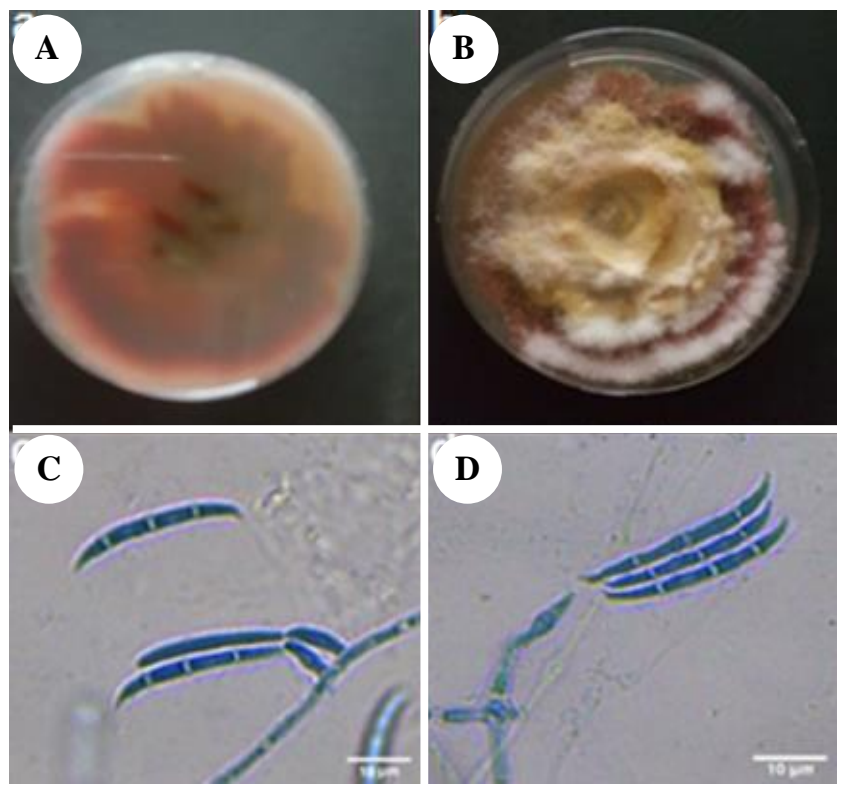

Figure 1. Morphological and microscopic characteristics of $F$. brachygibbosum colony after seven days on PDA at $25^{\circ}$ C. a: reverse view. b: surface growth (front view). c: and d: conidiophore; conidiogenous cell and macroconidia. (bar: $10 \mu \mathrm{m}$ )
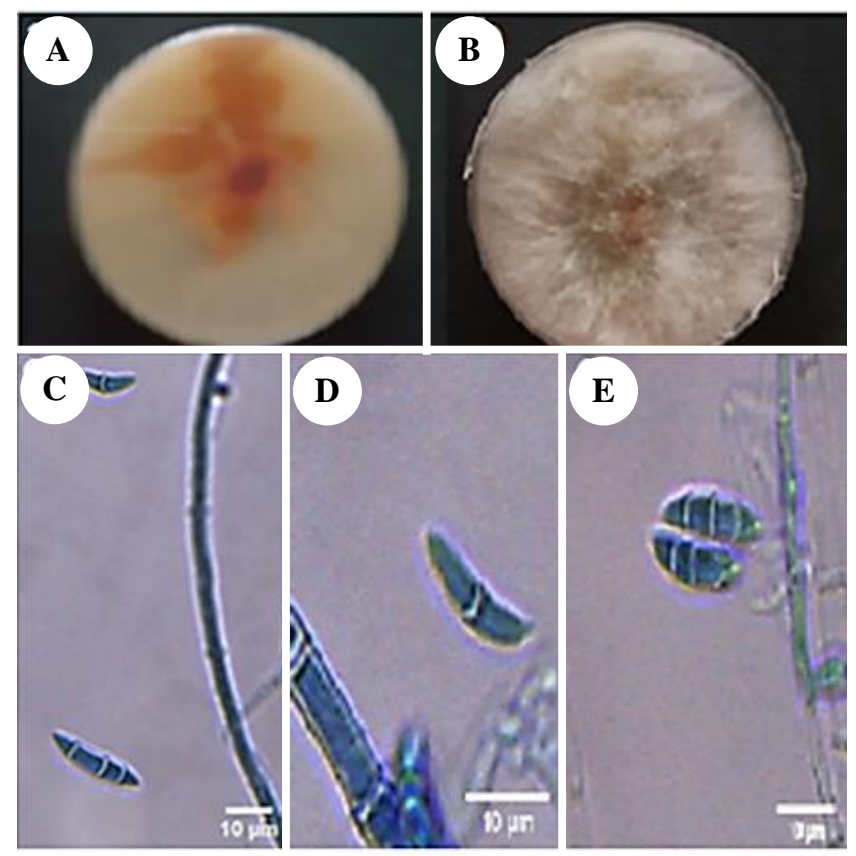

Figure 2. Morphological and microscopic characteristics of Fusarium falciforme colony after seven days on PDA at $25^{\circ} \mathrm{C}$. a: reverse view. b: surface growth (front view). c: macroconidium. $\mathrm{d}$ : microconidium. e: conidiophore and macroconidia. (bar: 10 $\mu \mathrm{m})$ 
Table 1. Pathogenicity test results of Fusarium brachygibbosum and F. falciforme on wheat plants

\begin{tabular}{lcccc}
\hline \multirow{2}{*}{ Disease parameter } & \multicolumn{2}{c}{ Fungal pathogens } & \multirow{2}{*}{ Week after inoculation } \\
\cline { 2 - 4 } & $\boldsymbol{F . \text { brachygibbosum }}$ & $\boldsymbol{F}$. falciforme & Control & $1^{\text {st }}$ week \\
Heading pathogenicity & $5.56 \%$ & $5.43 \%$ & 0 & $2^{\text {nd }}$ week \\
Means of disease severity $\%$ & $7.14 \%$ & $8.98 \%^{*}$ & 0 & $3^{\text {rd }}$ week \\
Damping-off & $7.14 \%$ & $12.46 \% *$ & 0 & \\
Seed germination & $6.61 \%$ & $8.95 \%$ & 0 & \\
Yellowing \% & 0 & 0 & 0 & \\
Necrosis \% on basal stem and crown & $100 \%$ & $100 \%$ & $100 \%$ & \\
\hline
\end{tabular}

Note: $*$ The mean difference is significant at the .05 level.

\section{Molecular identification of Fusarium species}

Molecular analysis of two Fusarium species was carried out using $(T E F-1 \alpha)$ gene. Sequencing analysis based on $\geq 99 \%$ sequence identity revealed the identity of $F$. brachygibbosum with the sequence identity of $100 \%$ of MF939166.1, as well as, $F$. falciforme with the sequence identity of $100 \%$ of KY906205.1. Phylogenetic tree illustrated that the Basra isolates of Fusarium species were clustered in one group for each corroborative with $100 \%$ bootstrap value. The first cluster comprised $F$. falciforme of GenBank accession number of KY556711.1; KY556710.1 and KY906205.1; while, the second cluster encompassed $F$. brachygibbosum of GenBank accession number MF939166.1; MF939165.1, and KY514170.1 (Figure 3).

\section{Pathogenicity test}

\section{Head pathogenicity}

Both fungal species had a mild effect on the wheat head as shown in Table (1). The mean of disease severity was $8.95 \%$ and $6.61 \%$ for $F$. falciforme and $F$. brachygibbosum, respectively. At the end of the first week after inoculation, the percentage of bleached heads $(5.43 \%$ and $5.56 \%$ ) was almost similar for both pathogens. Whereas, the percentage of disease severity for both pathogens was found different in the second and third weeks after inoculation. The percentage of disease severity in the second and third weeks was $8.98 \%$ and $12.46 \%$ respectively. For $F$. falciforme, there was a significant difference between the second and third weeks, while for $F$. brachygibbosum it was constant at $7.14 \%$ for both weeks.

\section{Stem, root, and seed pathogenicity}

Results did not show any effect on seed germination and damping-off at seedling stages in both pathogen treatments but had a slight effect on leaf yellowing with $8 \%$ and $5 \%$ for $F$. falciforme and $F$. brachygibbosum, respectively. The mean of disease severity (as necrosis on basal stem and crown) was $5 \%$ and $3.34 \%$ for $F$. falciforme and $F$. brachygibbosum, respectively. Only $20 \%$ of the tested wheat tillers showed necrosis symptoms on basal stems at scale $1(25 \%)$ with $F$. falciforme, while for $F$. brachygibbosum, only $13.33 \%$ of tested tillers showed spot symptoms on stems at scale $1(25 \%)$ (Figure. 4).

\section{Discussion}

Two different species of Fusarium namely $F$. brachygibbosum and $F$. falciforme have been isolated from wheat plants. F. brachygibbosum was isolated from the wheat root in the Al-Hwuir district. While, F. falciforme was obtained from the rhizosphere region of the wheat field located in Al-Qurna district, Basra province. No previous work has been published in Iraq on the isolation and description of both species ( $F$. brachygibbosum and $F$. falciforme). In previous literature, $F$. brachygibbosum was isolated as a true pathogen from several hosts including wild grass, oleander, watermelon, and cereal grains (Davari et al. 2014, El-Rabbat et al. 2018, Mirhosseini et al. 2014). Whereas, $F$. falciforme has been isolated from lima bean and Poaceae plants (Siahpoush and Darvishnia 2018, Sousa et al. 2017).

Morphological and microscopic analysis of each fungal colony was performed on PDA and SNA plates. The growth of $F$. brachygibbosum on each media was characterized by their off-white to pink color colony; colorless conidiophores and conidia; conidia were ellipsoidal to reniform and produced abundant elongated chlamydospores. This species produced different shapes of micro and macroconidia. Whereas, colony of $F$. falciforme was pinkish to blood-red color; and characterized by production of colorless conidiophores and aseptate conidia with an ellipsoidal shape. Elongated to swollen macroconidia were produced abundantly, and microconidia were oval-shaped.

The morphological and microscopic identification of both species has been confirmed by DNA sequence analysis of the gene TEF-1a. The molecular phylogenetic approaches have been extensively employed to facilitate accurate species identification in the genus Fusarium (Aoki et al. 2014). In this study, results confirmed the identity of $F$. brachygibbosum and $F$. falciforme with a sequence identity of $100 \%$ (GenBank accession number MF939166.1 and KY906205.1). TEF-1 $a$ gene sequencing has been used successfully in different Fusarium species identification such as $F$. verticillioides, $F$. subglutinans, $F$. sporotrichioides, F. poae, F. torulosum, F. sambucinum, and $F$. hostae (Rentería-Martínez et al. 2015), and $F$. keratoplasticum, $F$. falciforme, and $F$. cf. ensiforme (Chehri et al. 2015); F. proliferatum, $F$. brachygibbosum, $F$. oxysporum, and F. verticillioides (Saleh et al. 2017). 


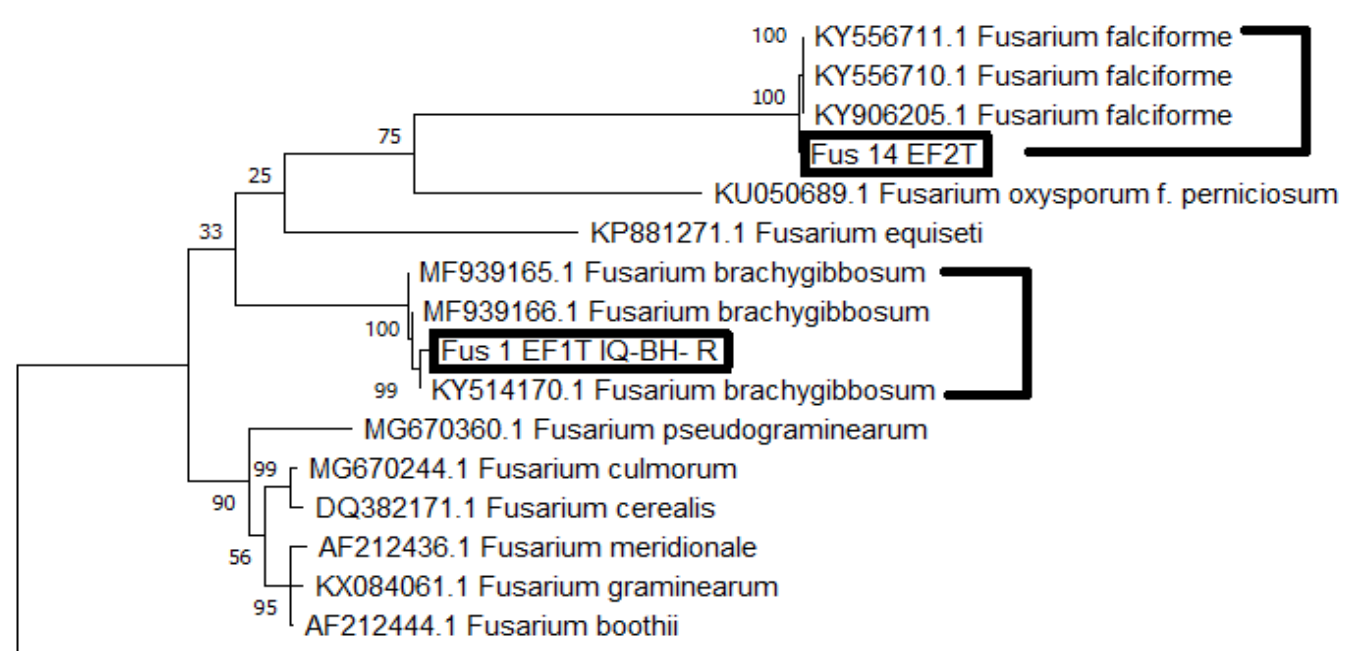

LC136861.1 Alternaria tenuissima

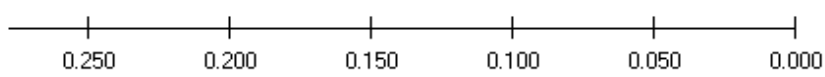

Figure 3. Phylogenetic tree inferred from maximum likelihood analysis and Kimura 2-parameter model of the partial sequences of the translation elongation factor $(T E F-1 \alpha)$ gene. Node numbers correspond to bootstrap values $>50 \%$ based on 1000 replicates. $F$. brachygibbosum and F. falciforme are indicated by black rectangles to be distinguished. Alternaria tenuissima (LC136861.1) was used to root the tree
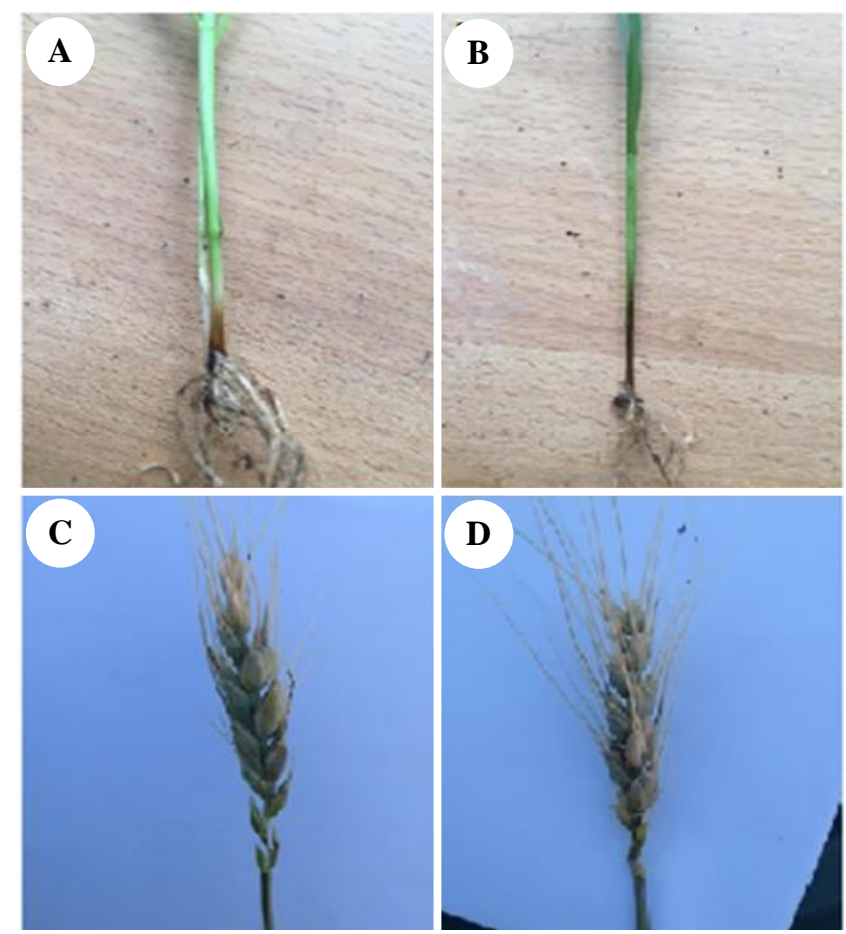

Figure 4. Disease symptoms on wheat plants. a. Crown necrosis symptoms caused by $F$. brachygibbosum. b. Stem necrosis symptoms caused by $F$. falciforme. c \& d. Bleached head symptoms caused by $F$. brachygibbosum and $F$. falciforme.

The translation elongation factor (TEF-1a) gene sequence encoded partially of protein translation machinery with a high level of sequence polymorphism which enables the differentiation of closest taxa including Fusarium complex species (Kristensen et al. 2005). Such molecular techniques had employed for the purpose of species identification as well as phylogenetic and taxonomic aims (O'Donnell et al. 2000). TEF gene sequencing as a conserved housekeeping gene provides a reliable procedure for fungal species identification, e.g. in Fusarium species as a single- locus technique (Geiser et al. 2004, Knutsen et al. 2004, Kristensen et al. 2005).

Neither the differentiation in pathogenicity of two identified Fusarium species (F. brachygibbosum and $F$. falciforme) nor the pathogenicity on wheat has been previously studied. Wong et al. (1995), have conducted pathogenicity tests of nine and seven Fusarium spp. on wheat crops respectively, and their results revealed that $F$. graminearum and $F$. culmorum were the only two high pathogenic species causing FHB. Xue et al.(2004) have added $F$. cerealis (crookwellense), because it is as another important pathogenic species causing FHB disease on wheat. $F$. avenaceum was reported to be weakly pathogenic on a certain wheat variety (Chevron) but was highly pathogenic on the other varieties (Gebremariam et al. 2018). In this study, F. falciforme and F. brachygibbosum were weakly pathogenic on Abu Ghraib 3 wheat variety (the only variety examined in this experiment), causing bleached head (as FHB) and necrosis symptoms on stem and crown (as FCR). Results suggest that these two Fusarium species may also be potentially significant FHB and FCR pathogens. Further studies should be conducted to investigate both Fusarium species on different wheat varieties available in Iraq and the effect of weather conditions in various geographic areas. 
In conclusion, both Fusarium species ( $F$. brachygibbosum and $F$. falciforme) have been isolated from wheat root and rhizosphere. Identification of pathogens was based on morphological and microscopic characteristics, as well as genetic identification was confirmed by applying TEF1- $\alpha$ gene sequencing on both species. To our knowledge, this is the first report in Iraq conducted to identify the two new pathogens on wheat plants. Results of pathogenicity test revealed the ability of examined Fusarium species to induce several disease symptoms on Iraqi wheat cultivar (Abu Graib 3); the symptoms including head bleaching, plant yellowing, and necrosis on stem and crown. Further studies should be conducted on the prevalence and severity of these pathogens on wheat plants and alternative hosts to evaluate their impact on production in Iraq.

\section{REFERENCES}

Al-Mahmooli I, Al-Bahri Y, Al-Sadi A, Deadman M. 2013. First report of Euphorbia larica dieback caused by Fusarium brachygibbosum in Oman. Plant Dis 97: 687-687. DOI: 10.1094/PDIS-09-12-0828-PDN.

Aoki T, O'Donnell K, Geiser DM. 2014. Systematics of key phytopathogenic Fusarium species: current status and future challenges. J Gen Plant Pathol 80: 189-201. DOI: 10.1007/s10327014-0509-3.

Basler R. 2016. Diversity of Fusarium species isolated from UK forage maize and the population structure of $F$. graminearum from maize and wheat. PeerJ 4: e2143. DOI: 10.7717/peerj.2143.

Chehri K, Salleh B, Zakaria L. 2015. Morphological and phylogenetic analysis of Fusarium solani species complex in Malaysia. Microb Ecol 69: 457-471. DOI: 10.1007/s00248-014-0494-2.

Davari M, Babai-Ahari A, Arzanlou M, Zare R, D Van Diepeningen A De Hoog G. 2014. Morphological and molecular characterization of three new Fusarium species associated with inflorescence of wild grasses for Iran. Rostaniha 14: 124-134.

El-Rabbat S, El-Maghraby O, El-Debaiky S, Haider A. 2018. Isolation and molecular identification of Fusarium species from some cereal grains and their products in Egypt. Int $\mathbf{J}$ Innov Sci Eng Technol 5: 2348-7968.

FAO. 2020. World Food and Agriculture - Statistical Yearbook 2020 FAO, Rome. DOI: 10.4060/cb1329en.

Gebremariam ES, Sharma-Poudyal D, Paulitz T, Erginbas-Orakci G, Karakaya A, Dababat A. 2018. Identity and pathogenicity of Fusarium species associated with crown rot on wheat (Triticum spp.) in Turkey. Eur J Plant Pathol 150: 387-399. DOI: 10.1007/s10658017-1285-7.

Geiser DM, del Mar Jiménez-Gasco M, Kang S, Makalowska I Veeraraghavan N, Ward TJ, Zhang N, Kuldau GA, O'Donnell K. 2004. FUSARIUM-ID v. 1.0: a DNA sequence database for identifying Fusarium. Eur J Plant Pathol 110: 473-479. DOI: 10.1007/978-1-4020-2285-2_2.

Knutsen A, Torp M, Holst-Jensen A. 2004. Phylogenetic analyses of the Fusarium poae, Fusarium sporotrichioides and Fusarium langsethiae species complex based on partial sequences of the translation elongation factor-1 alpha gene. Int J Food Microbiol 95: 287-295. DOI: 10.1016/j.ijfoodmicro.2003.12.007.

Kreft M. 2016. Buckwheat phenolic metabolites in health and disease. Nutr Res Rev 29: 30-39. DOI: 10.1017/S0954422415000190.

Kristensen R, Torp M, Kosiak B, Holst-Jensen A. 2005. Phylogeny and toxigenic potential is correlated in Fusarium species as revealed by partial translation elongation factor 1 alpha gene sequences. Mycol Res 109: 173-186. DOI: 10.1017/S0953756204002114.

Kumar S, Stecher G, Li M, Knyaz C, Tamura K. 2018. MEGA X: molecular evolutionary genetics analysis across computing platforms. Mol Biol Evol 35: 1547-1549. DOI: 10.1093/molbev/msy096.

Ledingham R, Atkinson T, Horricks J, Mills J, Piening L, Tinline R. 1973. Wheat losses due to common root rot in the prairie provinces of Canada, 1969-71. Can Plant Dis Surv 53: 113-122.
Leslie JF, Summerell BA. 2008. The Fusarium Laboratory Manual: John Wiley \& Sons, New York.

Minati MH, Mohammed-Ameen MK. 2019a. Novel report on six Fusarium species associated with head blight and crown rot of wheat in Basra province, Iraq. Bull Natl Res Cent 43: 139. DOI: 10.1186/s42269-019-0173-z.

Minati MH, Mohammed-Ameen MK. 2019b. Interaction between Fusarium head blight and crown rot disease incidence and cultural practices on wheat in the south of Iraq, Basra province. Bull Natl Res Cent 43: 1-11. DOI: 10.1186/s42269-019-0257-9.

Minati MH, Mohammed-Ameen MK. 2019c. Interaction between Fusarium head blight and crown rot disease incidence and environmental factors and soil physiochemical analysis on wheat in the South of Iraq, Basra Province. Karbala Int J Modern Sci 5: 6. DOI: $10.33640 / 2405-609 X .1168$

Minati MH, Mohammed-Ameen MK. 2019d. First report of three kinds of mycotoxins deoxynivalenol, nivalenol and fumonisin B2 in seeds of seven wheat cultivars in Iraq. Iraqi J Vet Med 43: 43-49. DOI: 10.30539/iraqijvm.v43i1.469.

Minati MH, Mohammed-Ameen MK. 2020. Co-occurrence of Fusarium head blight and crown rot on several wheat cultivars in the South of Iraq Basra Province. AIP Conf Proc 2213: 020001. DOI: 10.1063/5.0000108

Mirhosseini H, Babaeizad V, Hashemi L. 2014. First report of Fusarium brachygibbosum causing leaf spot on oleander in Iran. J Plant Pathol 96.

Nelson PE, Toussoun TA, Marasas W. 1983. Fusarium species: an illustrated manual for identification.

Nelson PE, Dignani MC, Anaissie EJ. 1994. Taxonomy, biology, and clinical aspects of Fusarium species. Clin Microbiol Rev 7: 479-504. DOI: 10.1128/CMR.7.4.479-504.1994.

O'Donnell K, Kistler HC, Tacke BK, Casper HH. 2000. Gene genealogies reveal global phylogeographic structure and reproductive isolation among lineages of Fusarium graminearum, the fungus causing wheat scab. Proc Nal Acad Sci 97: 7905-7910. DOI: 10.1073/pnas.130193297.

Polišenská I, Vaculová K, Jirsa O, Sedláčková I, Frydrych J. 2019. Yield and quality of two hulless barley varieties after inoculation with Fusarium culmorum. Kvasny Prumysl 65: 17-22. DOI: 10.18832/kp2019.65.17.

Punja ZK, Scott C, Chen S. 2018. Root and crown rot pathogens causing wilt symptoms on field-grown marijuana (Cannabis sativa L.) plants. Can J Plant Pathol 40: 528-541. DOI: 10.1080/07060661.2018.1535470.

Rentería-Martínez M, Meza-Moller A, Guerra-Camacho M, RomoTamayo F, Ochoa-Meza A, Moreno-Salazar S. 2015. First report of watermelon wilting caused by Fusarium brachygibbosum in Sonora, Mexico. Plant Dis 99: 729-729. DOI: 10.1094/PDIS-10-14-1073PDN

Saleh AA, Sharafaddin AH, El_Komy MH, Ibrahim YE, Hamad YK, Molan YY. 2017. Fusarium species associated with date palm in Saudi Arabia. Eur J Plant Pathol 148: 367-377. DOI: 10.1007/s10658016-1095-3

Shewry PR, Hey SJ. 2015. The contribution of wheat to human diet and health. Food Energy Secur 4: 178-202. DOI: 10.1002/fes3.64.

Siahpoush S, Darvishnia M. 2018. New Fusarium species from Poaceae in western Iran. Vegetos- An Int J Plant Res 31: 1-8. DOI: 10.5958/2229-4473.2018.00066.6

Sousa E, Melo M, Mota J, Sousa E, Beserra Jr J, Matos K. 2017. First report of Fusarium falciforme (FSSC 3+ 4) causing root rot in lima bean (Phaseolus lunatus L.) in Brazil. Plant Dis 101: 1954-1954. DOI: 10.1094/PDIS-05-17-0657-PDN.

Thokala P, Kamil D, Pandey P, Narayanasamy P, Mathur N. 2015. Combined approach of morphological and molecular diagnosis of Fusaria spp. causing diseases in crop plants. Recent Advances in the Diagnosis and Management of Plant Diseases, Springer. DOI: 10.1007/978-81-322-2571-3_3.

Trabelsi R, Sellami H, Gharbi Y, Krid S, Cheffi M, Kammoun S, Dammak M, Mseddi A, Gdoura R, Triki MA. 2017. Morphological and molecular characterization of Fusarium spp. associated with olive trees dieback in Tunisia. 3 Biotech 7: 28. DOI: 10.1007/s13205-0160587-3.

Tryon H. 1917. Report of the entomologist and vegetable pathologist. Rep Entomol Vegetable Pathol 49-63.

Wong L, Abramson D, Tekauz A, Leisle D, McKenzie R. 1995. Pathogenicity and mycotoxin production of Fusarium species causing 
head blight in wheat cultivars varying in resistance. Can J Plant Sci 75: 261-267. DOI: $10.4141 /$ cjps95-047.

Xue AG, Armstrong KC, Voldeng HD, Fedak G, Babcock C. 2004. Comparative aggressiveness of isolates of Fusarium spp. causing head blight on wheat in Canada. Can J Plant Pathol 26: 81-88. DOI: 10.1080/07060660409507117 